\title{
MANAJEMEN PENGELOLAAN DANA UNTUK MENINGKATKAN PROFITABILITAS DI KKS BAROKAH TANJUNGANOM NGANJUK
}

\author{
Oleh \\ Alfin Yuli Dianto \\ Institut Agama Islam Pangeran Diponegoro Nganjuk \\ alfinmaskur@iaipd-nganjuk.ac.id
}

\begin{abstract}
Management is very necessary in any case for financial institutions. Whether or not financial management is very important to the level of profitability of the institution itself. Profitability is the ability of a company or institution to find profits related to sales, total capital or capital itself. One of the fund management institutions that is currently mushrooming in the midst of the community is the Sharia Consumer Cooperative (KKS). But not a few KKS who fell freely in the middle of the road in less than five years. This is because of the weak implementation of management, management is carelessly. Funds that come in are not managed properly. This service is what makes researchers interested in studying the management process in the Nganjuk Barokah Tanjunganom KKS which lasts up to 6 years.
\end{abstract}

Keywords: Financial Management, Profitability, Syariah Consumer Cooperatives

\begin{abstract}
Abstrak
Manajemen dalam pengelolaan dana sangat diperlukan dalam hal apapun terutama lembaga pengelola keuangan. Baik dan tidaknya manajemen keuangan sangat berpengaruh terhadap tingkat profitabilitas lembaga itu sendiri. Profitabilitas merupakan kemampuan perusahaan atau lembaga dalam memperoleh laba yang hubungannya dengan penjualan, total aktiva maupun modal itu sendiri. Salah satu lembaga pengelola dana yang saat ini sedang menjamur di tengah-tengah masyarakat adalah Koperasi Konsumen Syariah (KKS). Namun tak sedikit KKS yang tumbang secara perlahan di tengah jalan dalam kurun waktu kurang dari lima tahun. Hal ini karena lemahnya penerapan manajemen, pengelolaan menjadi asal-asalan sehingga dana yang masuk tidak terkelola dengan baik.
\end{abstract}


Kondisi ini yang membuat peneliti tertarik untuk mengamati bagaimana proses manajamen di KKS Barokah Tanjunganom Nganjuk yang bertahan hingga 6 tahun.

Kata Kunci: Manajemen Keuangan, Profitabilitas, Koperasi Konsumen Syariah

\section{Pendahuluan}

Perkembangan dunia perekonomian yang semakin pesat membuat semua industri ataupun lembaga juga ikut terpengaruh khususnya perbankan yang melayani penyediaan jasa dalam skala industri kecil, menengah sampai besar dengan peraturan pelayanan yang sama dalam hal pengelolaan dan pengalokasian dana masyarakat. Disisi lain juga terdapat lembaga yang menangani permasalahan keuangan untuk usaha kecil dan menengah dengan proses dan juga peraturan yang lebih sederhana dan tidak menyulitkan dalam penangananya, lembaga yang masih bernaung dengan dinas koperasi dan mengikuti semua peraturan dan ketentuan yang telah dibuat oleh dinas perkoperasian, dan mengikuti apa yang telah disepakati oleh para ulama dalam proses usaha yang halal dan semua peratu dalam pelaksanaan usaha.

KKS (Koperasi Konsumen Syari'ah) atau biasa disebut juga koperasi syariah ini merupakan lembaga keuangan mikro dengan berbasis ekonomi umat atau ekonomi syariah. Pelaksanaan usaha dan semua pekerjaan dalam usaha ini berlandaskan pada peraturan yang terdapat pada Al Qur'an, Hadist, ijma' dan qiyas yang dilakukan oleh para ulama mengenai system perekonomian saat ini yang semakin maju.

Sebagai lembaga keuangan KKS harus dikelola secara professional, maka KKS harus menganut prinsip-prinsip manajemen. Oleh karena itu, KKS tidak boleh dikelola dengan asal-asalan. Setiap insan KKS haruslah mengikuti tren perkembangan lingkungan bisnisnya dengan melakukan inovasi-inovasi produk yang dilakukan dalam rangka merebut pasar. Tetapi juga tidak boleh menyalahi aturan atau ketentuan yang terdapat dalam syariat Islam tentang 
bermuamalah. Dalam pelaksanaanya KKS dilaksanakan berdasarkan prinsip kehati-hatian dan tolong-menolong. Bebas dari unsur riba.

Proses dalam transaksi baik dari sebuah lembaga yang sangat besar seperti halnya perbankan maupun lembaga keuangan dalam skala kecil seperti koperasi atau KKS membutuhkan sebuah kepercayaan yang sangat besar dari masyarakat karena usaha ini merupakan usaha yang menawarkan sebuah jasa, jasa untuk mengelola dana nasabah yang diberikan maupun jasa dalam hal ini penyediaan modal atau dana bagi masyarakat yang membutuhkan modal. Oleh karena itu sebuah lembaga haruslah melayani nasabah dengan sepenuh hati dan dengan menggunakan strategi yang sangat diperhitungkan dengan sebaik mungkin khususnya dalam hal perencanaan, pengorganisasian, pengarahan dan pengawasan dalam hal penggunaan dana nasabah dan memperhatikan sebuah peraturan yang telah dibuat, seperti peraturan yang telah disepakati oleh dinas koperasi dan UKM (Usaha Kecil Menengah).

Dalam pelaksanaanya KKS juga memiliki sistem yang sama dengan lembaga keuangan syariah, aktivitas usaha Bank atau Lembaga Keuangan lainya (KKS) dibagi menjadi dua, yaitu menghimpun dana dari masyarakat dalam bentuk simpanan, meliputi giro (wadi'ah), tabungan (wadi'ah dan murabahah) dan deposito (murabahah). Dan juga melakukan penyaluran dana melalui transaksi jual beli (murabahah, salam, ijarah dan istisna'), bagi hasil (mudharabah dan musyarakah), dan pembiayaan lainya (hiwalah, rahn, dan qard). ${ }^{45}$

Banyaknya produk yang ada di KKS membuat masyarakat banyak yang tertarik untuk menjadi anggota. Selain KKS berbasis syari'ah, dari segi beban bagi hasil untuk anggota pembiayaan lebih ringan dibandingkan dengan bank konvensional. Di KKS juga terdapat unsur ta'awun (tolong menolong). Dalam pengelolaan dana sebuah lembaga keuangan menggunakan rasio sebagai pengukuran

${ }^{45}$ Mohammad Ridwan, Manajemen Baitul maal wa Tamwil, Yogyakarta: UII Press, 2004,150 
untuk mempermudah dalam proses analisis dan mengevaluasi hasil kerja dan untuk menilai sebaik apa proses transaksi yang telah dijalankan dan sebagai bahan acuan untuk transaksi di bulan berikutnya.

Usaha yang dilakukan oleh koperasi atau lembaga keuangan mikro harus layak artinya usaha tersebut harus dikelola secara benar dan efisien dan mampu menghasilkan keuntungan atau SHU (Sisa Hasil Usaha) dengan memerhatikan faktor-faktor tenaga kerja, modal dan teknologi. Kegiatan penghimpunan dana dan penyaluran dana adalah kegiatan yang sangat penting dalam menjaga kelangsungan kegiatan di KKS maupun lembaga keuangan lainya. Oleh karena itu diperlukan rasio profitabilitas yang akan menjadi tolak ukur pada sebuah lembaga, dengan menggunakan perhitungan rasio profitabilitas maka akan dapat diketahui sejauh mana lembaga keuangan memperoleh laba untuk meningkatkan keuntungan dan mempertahankan keberlangsungan lembaga.

Salah satu pengukuran profitabilitas dapat diketahui melalui rasio non performing financing (NPF), yaitu rasio yang digunakan untuk mengukur kemampuan manajemen lembaga keuangan dalam mengelola pembiayaan yang bermasalah yang ada dapat dipenuhi dengan aktiva produktif yang dimiliki oleh suatu lembaga keuangan. ${ }^{46}$ Pengukuran tingkat profitabilitas dapat dilakukan dengan membandingkan tingkat Return on Investment (ROI) yang diharapkan dengan tingkat return yang diminta para investor dalam pasar modal. Jika return yang diharapkan lebih besar dari pada return yang diminta, maka investasi dikatakan menguntungkan. ${ }^{47}$

Di lembaga keuangan KKS Barokah Tanjunganom dalam melihat tingkat profitabilitas selain dari laporan laba rugi hasil usaha selama beberapa waktu juga melalui tingkat NPF yang dicapai selama beberapa periode dengan melihat tinggi rendahnya penyelesaian

${ }^{46}$ Ibid., 4

${ }^{47}$ Manahan P. Tampubolon, Manajemen Keuangan (Konseptual, Problem, dan Studi Kasus), Bogor: Ghalia Indonesia, 2005, 38 
pembiayaan bermasalah. Selain menjaga laporan keuangan di KKS dan menjaga laporan kolektabilitas agar tetap pada batas yang normal, pihak KKS juga menerapkan peraturan, sanksi, beserta dewan pengawas baik dari kantor capem sendiri maupun pengawas yang langsung dari pusat, untuk memantau seluruh kegiatan KKS baik kegiatan operasional maupun kinerja karyawan di KKS itu sendiri. Selain setiap peraturan yang dibuat oleh KKS Barokah Tanjunganom sendiri dalam menjalankan kegiatan operasionalnya juga terdapat peraturan dari Menteri Koperasi dan Usaha kecil dan Menengah Republik Indonesia mengenai penilaian kesehatan koperasi Nomor : 14/Per/M.Kukm/XII/2009. Oleh karena itu, peneliti tertarik untuk melihat pentingnya proses manajemen dalam pengelolaan dana yang sangat berpengaruh terhadap tingkat profitabilitas.

\section{Metode Penelitian}

Dalam Penelitian ini menggunakan pendekatan kualitatif yang memusatkan pada penerapan fungsi manajemen dalam meningkatkan kepuasan anggota . Menurut Lexi J. Moleong yang mendefinisikan penelitian kualitatif adalah prosedur penelitian yang menghasilkan data-data deskriptif berupa kata-kata tertulis atau lisan dari orangorang dan perilaku yang diamati. ${ }^{48}$ Penelitian ini menggunakan jenis penelitian deskriptif, yaitu penelitian yang dilakukan untuk meneliti status sekelompok manusia, suatu obyek, suatu kondisi,dan suatu sistem pemikiran ataupun suatu kelas peristiwa pada masa sekarang . Tujuan dalam penelitian ini adalah membuat deskripsi, gambaran atau lukisan secara sistematis, factual atau akurat mengenai fakta-fakta, sifat-sifat atau hubungan antaran fenomena yang diselidiki, yaitu tentang penerapan fungsi manajemen dalam meningkatkan kepuasan anggota. Proses pengumpulan data ada beberapa prosedur yang

${ }^{48}$ Lexi J Moleong, Metodologi Penelitian Kualitatif, Bandung, Remaja Rosda Karya, 2012,hal 2 
dilalui oleh peneliti yaitu metode interview (wawancara), observasi (pengamatan), dan dokumentasi. ${ }^{49}$

\section{Hasil Dan Pembahasan}

\section{Manajemen Kunci Keberhasilan}

Manajemen berasal dari bahasa latin yaitu dari kata manus yang berarti tangan dan agere yang berarti melakukan. Kata-kata itu digabung menjadi managere yang artinya menangani. Managere diterjemahkan ke Bahasa Inggris to manage (kata kerja), management (kata benda), manager untuk orang yang melakukannya, dan management diterjemahkan ke Bahasa Indonesia menjadi manajemen (pengelolaan). ${ }^{50}$ Jadi, manajemen itu merupakan suatu proses untuk mewujudkan tujuan yang diinginkan. Karena manajemen diartikan sebagai mengatur, maka timbul beberapa pertanyaan, diantaranya:

1) Apa yang diatur? Yang diatur adalah semua unsur-unsur manajemen dan semua aktivitas yang di timbulkan dalam proses manajemen.

2) Kenapa harus diatur? Agar unsur manajemen lebih berdaya guna, berhasil guna, terintegrasi, dan terkoordinasi dalam mencapai tujuan yang optimal.

3) Siapa yang mengatur? Yang mengatur adalah pemimpin dengan wewenang kepemimpinannya melalui instruksi atau persuasi, sehingga unsur-unsur manajemen dan semua proses manajemen tertuju serta terarah kepada tujuan yang diinginkan.

4) Bagaimana mengaturnya? Mengaturnya yaitu melalui proses dari urutan fungsi-fungsi manajemen.

5) Dimana harus diatur? Dalam suatu organisasi atau perusahaan, karena organisasi merupakan "alat" dan "wadah" semua aktivitas manajemen untuk mencapai tujuannya. ${ }^{51}$

\footnotetext{
${ }^{49}$ Suharsini Arikunto, Prosedur Penelitian Suatu Pendekatan

Praktik, Jakarta: Rineka Cipta, 2013,275

${ }^{50}$ Husaini Usman, Manajemen Teori, Praktik, dan Riset

Pendidikan,Jakarta:Bumi Aksara,2013, 06

${ }^{51}$ Malayu S.P. Hasibuan,Manajemen Dasar,Pengertian dan

Masalah,Jakarta:Bumi Aksara,2015, 2.
} 
Sedangkan pengertian manajemen menurut beberapa tokoh adalah sebagai berikut:

Menurut G.R Terry manajemen merupakan suatu proses yang khas yang terdiri dari tindakan-tindakan perencanaan, pengorganisasian, pengarahan, dan pengendalian yang dilakukan untuk menentukan serta mencapai sasaran-sasaran yang telah ditentukan melalui pemanfaatan sumber daya manusia dan sumbersumber lainnya. ${ }^{52}$ Dari berbagai definisi tentang manajemen dapat diambil kesimpulan bahwa manajemen mempunyai lima fungsi, yaitu:

1. Perencanaan

2. Pengorganisasian

3. Pengarahan

4. Pengkoordinasian

5. Pengawasan

Fungsi manajemen adalah elemen-elemen dasar yang akan selalu ada dan melekat di dalam proses manajemen yang dijadikan acuan oleh manajer dalam melaksanakan kegiatan untuk mencapai tujuan. Fungsi manajemen pertama kali dikenalkan oleh seorang industrialis perancis bernama Henry Fayol pada awal abad 20. Saat itu dia menyebutkan bahwa terdapat lima fungsi manajemen, merancang, mengorganisir, memerintah, mengodinasi, dan mengendalikan. Namun saat ini kelima fungsi tersebut telah diringkas menjadi empat bagian yaitu:

\section{Perencanaan (Planning)}

Merupakan proses memikirkan apa saja yang harus dilakukan dengan usaha atau sumber daya yang dimiliki. Perencanaan dilakukan untuk menentukan tujuan perusahaan secara keseluruhan dan cara terbaik untuk memenuhi tujuan itu. Manajer mengevaluasi setiap rencana alternative sebelum mengambil sebuah keputusan dan kemudian memilih rencana yang sesuai dengan tujuan perusahaan. Perencanaan merupakan proses penting dari semua fungsi manajemen karena tanpa perencanaan, fungsi-fungsi lainya tak dapat berjalan dengan baik. Dalam perencanaan ini diterapkan tujuan yang ingin

\footnotetext{
${ }^{52}$ loc. cit.
} 
dicapai, pedoman pelaksanaan kegiatan, pembagian kerja, pengarahan dan pengendalian.

Contoh lain dari perencanaan yang dilakukan Rasulullah Saw dapat ditemukan ketika terjadi perjanjian Hudaibiyyah (shulhul Hudaibiyyah). Dari perjanjian tersebut terkesan Rasulullah Saw kalah dalam berdiplomasi dan terpaksa menyetujui beberapa hal yang berpihak kepada kafir Quraisy. Kesan tersebut ternyata terbukti sebaliknya setelah perjanjian tersebut disepakati. Disinilah terlihat kelihaian Rasulullah Saw dan pandangan beliau yang jauh ke depan. Rasulullah Saw adalah insan yang selalu mengutamakan kebaikan yang kekal dibandingkan kebaikan yang hanya bersifat sementara. Walaupun perjanjian itu amat berat sebelah, Rasulullah Saw menerimanya karena memberikan manfaat di masa depan saat umat Islam berhasil membuka kota Mekkah (fath al Makkah) pada tahun ke-8 Hijriyah (dua tahun setelah perjanjian Hudaibiyah).

2. Pengorganisasian (Organizing)

Organizing merupakan suatu kegiatan yang dilakukan dengan membagi suatu kegiatan besar menjadi kegiatan yang lebih kecil.Pengorganisasian mempermudah manager dalam melakukan pengawasan pada setiap pekerjaan yang ada, proses ini juga digunakan untuk menentukan orang yang dibutuhkan untuk melaksanakan tugastugas yang telah dibagi-bagi tersebut.pengorganisasian dapat dilakukan dengan cara menentukan tugas apa yang harus dikerjakan, siapa yang harus mengerjakan, bagaimana tugas tersebut dikelompokkan, siapa yang bertanggung jawab atas tugas tersebut, pada tingkat mana keputusan diambil.

3. Pengarahan (Actuating)

Merupakan suatu tindakan untuk mengusahakan agar semua anggota kelompok berusaha untuk mencapai sasaran sesuai dengan perencanaan manajerial dan usaha.Pengarahan merupakan pekerjaan yang tidak mudah untuk dilakukan karena berkaitan langsung dengan manusia tersebut yang mempunyai pikiran, perasaan, harga diri dan kemauan. Agar sebuah pengarahan dapat berjalan dengan lancar pemimpin harus lebih memerhatikan masalah-masalah "perilaku manusia, kepemimpinan, koomunikasi dan hubungan manusia". 
Dalam pemberian pengarahan, juga digunakan instruksi-instruksi yang menunjang pengetahuan mengenai aspek untuk melaksanakan suatu tugas tertentu. Untuk dapat melaksanakanya juga diberi data yang terperinci mengenai situasi, dan urutan langkah-langkah yang harus ditempuh. Instruksi-instruksi memang sulit dituliskan dan dapat menyita lebih banyak waktu namun akan semakin banyak.

4. Pengendalian (Controling)

Controlling merupakan cara mengukur pelaksanaan dengan tujuan-tujuan menentukan sebab-sebab penyimpangan-penyimpangan dan mengambil tindakan-tindakan korektif dimana perlu. Contoh pengawasan dari fungsi manajemen dapat dijumpai dalam haditsyang diriwayatkan oleh Imam Bukhari sebagai berikut:

Al Bukhari Muslim meriwayatkan dari Ibnu Abbas, ia berkata: "Suatu malam aku menginap di rumah bibiku, Maimunah. Setelah beberap saat malam lewat, Nabi bangun untuk menunaikan shalat. Beliau melakukan wudhu' ringan sekali (dengan air yang sedikit) dan kemudian shalat. Maka, aku bangun dan berwudhu seperti wudhu Beliau. Aku menghampiri Beliau dan berdiri di sebelah kirinya. Beliau memutarku ke arah sebelah kanannya dan meneruskannshalatnya sesuai yang dikehendaki Allah ...”.23

Dari peristiwa di atas dapat ditemukan upaya pengawasan Nabi Muhammad SAW terhadap Ibnu Abbas yang melakukan kesalahan karena berdiri di sisi kiriBeliau saat menjadi makmum dalam shalat bersama Beliau. Karena seorangmakmum harus berada di sebelah kanan imam, jika ia sendirian bersama imam. Beliau Shallallahu 'alaihi wa sallam tidak membiarkan kekeliruan Ibnu Abbas dengan dalih umurnya yang masih dini, namun Beliau Shallallahu 'alaihi wasallam tetap mengoreksinya dengan mengalihkan posisinya ke kanan BeliauShallallahu 'alaihi wa sallam. Dalam melakukan pengawasan, beliau langsungmemberi arahan dan bimbingan yang benar.

\section{Pengelolaan Dana dan Profitabilitas}

Pengelolaan adalah penyelenggaraan,pengurus atau proses yang membantu merumuskan kebijaksanaan dan tujuan organisasi. 
Pengolahan sama halnya dengan manajemen, karena pengelolaan dalam sebuah organisasi memerlukan pelaksanaan tanggung jawab manajerial secara terus menerus. Dan tanggung jawab tersebut secara kolektif sering disebut dengan fungsi manajemen. Pengelolaan pada penelitian ini adalah serangkaian proses atau kegiatan yang meliputi perencanaan, pelaksanaan (pengorganisasian dan pengarahan), dan pengawasan atau pengendalian terhadap sumber-sumber pendapatan asli desa. Penjelasan mengenai pengelolaan pada penelitian ini, terdiri atas bagian perencanaan, kemudian pelaksanaan yang didalamnya termasuk mengenai pengorganisasian dan pengarahan, dan selanjudnya yang terakhir yaitu mengenai pengawasan atau pengendalian.

Berkaitan dengan aktivitas pengelolaan, seorang menejer dituntut untuk mampu melaksanakan berbagai kegiatan yang menjadi tanggung jawabnya, tak terkecuali dalam hal pengelolaan dana oraganisasi. Mengingat dana merupakan salah satu unsur yang sangat signifikan dalam upaya pencapaian tujuan sebuah organisasi, maka konsentrasi yang penuh dalam pengelolaanya perlu untuk dilakukan. Oleh karenanya, pengelola dalam tubuh organisasi merupakan salah satu hal yang terpenting dalam upaya mewujudkan semua hal agar menjadi lebih baik.

Selanjutnya tentang pengertian Profitabilitas yaitu kemampuan perusahaan memperoleh laba dalam hubungannya dengan penjualan, total aktiva maupun modal sendiri. Analisis rosio merupakan bentuk umum dari analisis finansial yang menyediakan ukuran relatif dari kinerja perusahaan. Informasi yang menjadi dasar perhitungan rasio finansial berasal dari laporan keuangan, yaitu neraca (balance sheet) dan laporan laba rugi (income statement). ${ }^{53}$ Data laporan keuangan dapat digunakan untuk menentukan berbagai rasio yang berhubungan dengan kinerja perusahaan. Menurut Gitman dalam Sugihen (2003), rasio keuangan yang paling umum digunakan untuk mengukur kinerja keuangan perusahaan adalah rasio profitabilitas.

${ }^{53}$ https://www.indosaja.com/pengertian profitabilitas menurut para ahli/(Online) diakses tanggal 24 Pebruari 2018 Pukul 11.30 
Kemampulabaan (profitabilitas) merupakan hasil akhir bersih dari berbagai kebijakan dan keputusan manajemen. Rasio kemampulabaan akan memberikan jawaban akhir tentang efektivitas manajemen perusahaan, rasio ini memberi gambaran tentang tingkat efektivitas pengelolaan perusahaan. Rasio profitabilitas yang umum digunakan antara lain:

1. Marjin Laba Kotor (Groos Profit Margin)

2. Gross Profit Margin=(Sales-Cost of Good Sold) $/$ Sales

Rasio profitabilitas ini mengukur efisiensi pengendalian harga pokok atau biaya produksinya, mengindikasikan kemampuan perusahaan untuk perusahaan untuk berproduksi secara efisien. Dalam mengevaluasi dapat dilihat margin per unit produk, bila rendah maka perusahaan tersebut sensitif terhadap pesaingnya.

\section{Sejarah Singkat Berdirinya KKS Barokah Tanjunganom}

KKS Barokah terletak di jalan Ahmad Yani Gg. Duren No.2 Tanjunganom Nganjuk jarak kantor KKS Barokah dari pusat kota Nganjuk \pm 16 KM. KKS Barokah pada awal berdirinya bernama KSU Barokah yang didirikan pada tahun 1998 dengan badan hukum no. 019/BH/KDK/13/IX/98. Kemudian pada awal tahun 2012 hasil dari Rapat Anggota Tahunan disepakati untuk membentuk unit usaha BMT (Baitul Maal Wattamwil atau Balai Usaha Mandiri Terpadu) atau unit Usaha Simpan Pinjam Pembiayaan Syari'ah (USPPS) yang pada awalnya unit usaha ini diberi nama BMT Barokah Amanah Syariah dan mulai berjalan pada tanggal 28 bulan April tahun 2012. Penamaan unit usaha Barokah Amanah Syariah mengandung filosofi karena pendiri menginginkan sebuah lembaga yang selain bisa mengemban amanah sebagai tempat untuk menyalurkan dana dari masyarakat kepada masyarakat lain yang membutuhkan secara syariah dan diharapkan juga kegiatan yang dijalankan mendapatkan keberkahan dari Allah SWT.

Tujuan dibentuknya unit usaha ini karena pendiri melihat banyak anggota koperasi dan masyarakat sekitar yang terjerumus pada praktek muamalah ribawi, rentenir dan perbankan konvensional yang memberatkan masyarakat dalam mengembangkan usahanya, 
khususnya pengusaha-pengusaha kecil, mereka merasa ekonominya tidak stabil dan banyak keluhan yang terjadi maka akhirnya muncullah gagasan dari pendiri untuk mendirikan unit usaha BMT atau USPPS ini, sebuah lembaga keuangan syariah yang benar-benar ingin menjalankan ekonomi secara syairah, dengan tekad dan semangat yang kuat untuk menolong masyarakat khususnya usaha-usaha kecil, sehingga dengan munculnya unit usaha simpan pinjam dan pembiayaan syariah ini masyarakat dapat terbantu.

Selanjutnya atas saran dari Dinas Perindustrian, Perdagangan, Koperasi, Pertambangan dan Energi (Disperindagkoptamben) Kabupaten Nganjuk, pengurus koperasi mengurus permohonan Perubahan Anggaran Dasar (PAD), untuk menambahkan unit BMT atau Unit Simpan Pinjam Pembiayaan Syariah ke dalam usaha koperasi. Akhirnya Pada tanggal 7 Februari 2014 KSU Barokah mendapatkan Akta Perubahan Anggaran Dasar dengan nomor 065/PAD/372.BH/426.101/2014 yang juga meresmikan perubahan bentuk koperasi dari KSU menjadi KJKS.

Namun, Selanjutnya setelah melalui berbagai workshop dan diklat yang diikuti oleh pengurus ataupun karyawan USPPS baik yang diadakan oleh Dinas Koperasi Propinsi Jawa Timur (Balatkop) di Malang maupun yang diadakan oleh pengurus Forum Komunitas Koperasi Syariah Jawa Timur (FKKS JATIM), serta saran dari berbagai pihak, dirasa lebih tepat apabila KJKS Barokah melakukan PAD lagi menjadi KKS (Koperasi Konsumen Syariah), karena bisa mengakomodir unit usaha selain USPPS yang lebih dahulu dijalankan oleh koperasi. Sebab KJKS dinilai lebih tepat digunakan oleh koperasi yang hanya memiliki USPPS saja, bukan untuk unit usaha retail. Sehingga pada tanggal 1 April 2016, KJKS Barokah resmi berubah menjadi KKS Barokah dengan Akta Perubahan Anggaran Dasar nomor 065/PAD/408.BH/426.101/2016.

KKS Barokah dalam memperoleh permodalannya berasal dari tiga sumber. Pertama, dari modal sendiri, yaitu modal yang berasal dari dana cadangan koperasi dan simpanan anggota (simpanan pokok dan simpanan wajib). Kedua, dari simpanan khusus anggota, yang diolah dalam produk simpanan mudharabah dan simpanan berjangka 
mudharabah. Ketiga, modal kerjasama pihak ketiga dan lembaga keuangan syari'ah. Sedangkan dalam pengelolaannya, KKS Barokah membuat produk pembiayaan syariah, yaitu : Produk Pembiayaan Kerjasama Bagi Hasil (Pembiayaan Mudharabah), Produk Pembiayaan Jual Beli (Pembiayaan Murabahah), dan Produk Pembiayaan Jasa / Sewa (Ijarah).

\section{Pelaksanaan Manajemen Pengelolaan Dana di KKS Barokah Tanjunganom}

Berkaitan dengan manajemen pengelolaan dana yang ada di KKS Barokah Tanjunganom, pelaksanaan manajemen saat ini dikelola pada beberapa unit usaha diantaranya, properti, retail, dan USPPS. Dari ketiga unit tersebut memiliki proses manajemen yang berbedabeda. Untuk unit usaha properti, pelaksanaan manajemennya dalam bentuk uang digunakan untuk pembelian aset dagangan berupa tanah, ruko, atau rumah baik itu untuk disewakan maupun dijual kembali. Dan untuk unit usaha retail, pelaksanaan manajemenya berupa pemberian modal di bidang pengecer. Sedangkan untuk unit usaha USPPS dalam pelaksanaan manajemennya dengan membuat produk produk pembiayaan. ${ }^{54}$

Ada beberapa unit usaha yang sudah tidak berjalan pada saat ini, yaitu unit usaha sembako dan unit usaha jual beli barang bekas. Hal ini disebabkan oleh harga sembako yang sangat labil, kurang loyalnya anggota koperasi untuk berbelanja sembako di koperasi, padahal harga yang diberikan koperasi sangat bersaing dengan di tempat lain, Banyak anggota yang berhutang saat berbelanja di koperasi, sehingga mengganggu kinerja / keuangan koperasi, padahal saat berbelanja di tempat lain bayar tunai. Untuk menghindari kerugian yang lebih besar, maka unit usaha sembako dan jual beli barang bekas ditutup.

Dari uraian diatas menunjukkan bahwa pengelolaan dana di KKS Barokah Tanjunganom, telah sesuai dengan yang terdapat dalam

\footnotetext{
${ }^{54}$ Hasil Wawancara dengan Manajer KKS Barokah Tanjunganom tanggal 1 Maret 2018
} 
teori. Pengalokasian dana KKS harus selalu berorientasi untuk meningkatkan kesejahteraan anggota, untuk itu pengalokasian dana KKS harus memperhatikan aspek :

1. Aman, yaitu dana KKS dapat dijamin pengembalianya

2. Lancar, yaitu perputaran dana dapat berjalan dengan cepat

3. Menghasilkan, yaitu pengalokasian dana harus dapat memberikan pendapatan maksimal

4. Halal, artinya pengalokasian dana KKS harus pada usaha yang halal, baik dari tinjauan hukum maupun agama

5. Diutamakan untuk pengembangan usaha ekonomi anggota. ${ }^{55}$

Berkaitan dengan tingkat profitabilitas yang diperoleh KKS Barokah Tanjunganom, peneliti menanyakan kepada Bapak Vebri Perwira Rosyadi, selaku manajer di KKS Barokah Tanjunganom, dia mengatakan bahwa selama 2 tahun terakhir, mulai tahun $2016 \mathrm{KKS}$ Barokah senantiasa mengalami peningkatan keuntungan. Profitabilitas KKS Barokah mengalami peningkatan sebesar 23\% dari Rp 15.903.734 menjadi Rp 19.541.405. Sedangkan pada tahun 2017 mengalami peningkatan sebesar $111 \%$ dari $\mathrm{Rp} 19.541 .405$ menjadi $\operatorname{Rp} 41.238 .527 .^{56}$

\section{Kesimpulan}

Berdasarkan paparan data, temuan penelitian dan pembahasan penelitian yang dilakukan maka diperoleh kesimpulan bahwa pelaksanaan manajemen pengelolaan dana di KKS Barokah Tanjunganom. Berdasarkan hasil wawancara yang telah dilakukan oleh peneliti terhadap pengelolaan dana di KKS Barokah Tanjunganom menunjukkan bahwa perolehan dana dari pihak ketiga sangat berpengaruh terhadap keuntungan atau tingkat profitabilitas yang dimiliki oleh KKS Barokah, selain itu operasional yang tepat dan ketepatan dalam penyaluran pembiayaan atau pemanfaatan perolehan dana dari pihak ketiga sangat mempengaruhi keuntungan KKS

\footnotetext{
${ }^{55}$ Ridwan, Manajemen ..., 159

${ }^{56}$ Hasil Wawancara dengan Manajer KKS Barokah Tanjunganom tanggal 1 Maret 2018
} 
Barokah. Dengan adanya analisis manajemen dalam setiap pekerjaan atau operasional KKS Barokah akan lebih terstruktur dan lebih efisien dalam meningkatkan kualitas kerja meupun peningkatan pendapatan dalam melaksanakan operasional.

Sedangkan faktor yang mendukung dan menghambat tingkat profitabilitas di KKS Barokah Tanjunganom yaitu a) Anggota tertib membayar angsuran, b) Banyak anggota yang mengambil produk pembiayaan mudharabah, c) Cash Flow lancar. Adapun faktor-faktor yang menghambat tingkat profitabilitas KKS Barokah antara lain a) Anggota tidak tertib membayar angsuran, b) Anggota yang mengambil produk pembiayaan mudharabah sedikit, c) Non Performance Landing (NPL) tinggi, d) Cash Flow tidak lancar.

\section{Saran}

1. Untuk KKS Barokah Tanjunganom. Berpaku dari hasil penelitian diatas, sebaiknya KKS Barokah Tanjunganom dapat memaksimalkan dana yang diperoleh dengan berinovasi lagi terhadap produk yang ada dan terus menjalankan aktivitasnya dengan berdasar pada peraturan-peraturan syariah. Serta lebih selektif lagi dalam menyetujui pembiayaan dengan memperketat persyaratan yang harus dipenuhi dan terus melakukan monitoring terhadap usaha nasabah serta terus menjaga silaturahmi dengan anggota.

2. Untuk karyawan KKS Barokah Tajunganom. Diharapkan untuk karyawan KKS Barokah Tajunganom lebih semangat lagi dalam menjalakan kinerja, serta lebih selektif dalam menjalankan survey terhadap anggota pengajuan pembiayaan. Memperbanyak sosialisasi kepada masyarakat dan membangun relasi yang baik kepada seluruh anggota KKS.

3. Untuk peneliti yang akan datang. Diharapkan peneliti yang akan datang dapat mengembangkan pengetahuan yang berkaitan dengan proses manajemen dalam pengelolaan dana terhadap tingkat profitabilitas KKS Barokah Tanjunganom dengan catatan kekurangan yang terdapat dalam penelitian ini hendaknya diperbaiki dan dijadikan acuan untuk lebih baik lagi 


\section{Daftar Pustaka}

Binti Nur Asiyah, Manajemen Pembiayaan Bank Syariah, Yogyakarta: Teras, 2014, 73

Mohammad Ridwan, Manajemen Baitul maal wa Tamwil, Yogyakarta: UII Press, 2004,150

Manahan P. Tampubolon , Manajemen Keuangan (Konseptual,

Problem, dan Studi Kasus), Bogor: Ghalia Indonesia, 2005, 38

Husaini Usman, Manajemen Teori, Praktik, dan Riset Pendidikan, Jakarta: Bumi Aksara,2013, 06

Malayu S.P. Hasibuan, Manajemen Dasar, Pengertian dan Masalah,Jakarta: Bumi Aksara,2015, 2.

Abdul Choliq, Pengantar Manajemen, Semarang: Rafi sarana Perkasa, 2011, 3

Swastha DH Basu dan Ibnu Sukotjo, Pengantar Bisnis Modern, Yogyakarta: Liberty, 2007, 82

Al Qur'an dan Terjemahnya, Departemen Agama, 2001

Husaini Usman, Manajemen Teori, Praktik, dan Riset Pendidikan, Jakarta Timur: PT Bumi Aksara, 2013, 38

Lexi J Moleong, Metodologi Penelitian Kualitatif, Bandung, Remaja Rosda Karya, 2012,hal 2

Lexy Moleong, Metodologi Penelitian. Bandung: Remaja Rosda Karya, 2002, 157.

Suharsini Arikunto, Prosedur Penelitian Suatu Pendekatan Praktik, Jakarta: Rineka Cipta, 2013,275

Alfiani Gistyaning Putri, Metode Pengumpulan Data (online), 2016, http://fitwiethayalisyi.wordpress.com ( 11 Januari 2018 )

Satori, Djam'an dan Aan Komariyah, Metode Penelitian Kualitatif: Bandung: Alfabeta, 2012,117

Lexy J. Moleong, Metodologi Penelitian Kualitatif, (Bandung: Remaja Rosdakarya, 2012), 103

Sugiyono, Metode Penelitian Kualitatif dan R\&D, Bandung: Alfabeta, 2012, 121 
Jurnal Dinamika Ekonomi Syariah

http://ejurnal.iaipd-nganjuk.ac.id/index.php/es

p-ISSN: 2654-3567

Sanjaya Andika, Uji Keabsahan Data Pada Penelitian

Kualitaif, musicalandpsychologist.blogspot.com (13 Januari 2018) 